\title{
Brexit will damage health
}

\author{
You can help ensure a people's vote on the final deal
}

\section{Fiona Godlee editor in chief, The BMJ, Donna Kinnair acting chief executive and general secretary, Royal College of Nursing, Chaand Nagpaul chair of council, BMA}

Within the next few weeks, the UK House of Commons is expected to vote on the withdrawal agreement to exit the EU. The prime minister has said that the choice for MPs will be between the "Chequers deal"1 if and in what guise it still exists, and, by default if this is not approved, a "no deal" Brexit. We are concerned that either outcome has the potential to cause serious and lasting damage to the nation's health. ${ }^{2}$ You may think there is nothing you can do to influence these events. This editorial, jointly from the BMA, the Royal College of Nursing, and The BMJ, seeks to persuade you otherwise.

Concern about the damaging effects of a no deal Brexit has intensified as the consequences have become clearer and the date of departure approaches. It is now widely accepted that the UK's economy will be badly hit, with inevitable cuts to funding for health and social care. But a no deal Brexit also poses serious immediate and long term threats to the supply of medicines and devices, to staffing for health and social care, to research funding and collaboration, and to public health. ${ }^{34}$

\section{Real risks}

Suppliers, civil servants, and ministers agree that a no deal Brexit would severely disrupt complex supply chains. No matter what the government is asking health professionals to tell their patients, ${ }^{56}$ the result would be dangerous shortages of medicines and devices. ${ }^{7}$ Contingency plans for stockpiling are in progress, but whether the proposed six week supply will be either feasible or sufficient is unclear. Especially vulnerable to shortages are biological medicines, analogue insulins, and substances of human origin such as plasma products, most of which are imported. These will require cold storage, which is itself in short supply and under increased demand from the food industry. Medical isotopes are almost all imported and cannot be stockpiled because of short half lives. ${ }^{8}$ Moving from ferry and lorry routes to airfreight would require expensive new infrastructure. And of course, at the heart of each of these scenarios are individual patients whose health would be put at risk.

As for the workforce, the vote to leave the EU has already exacerbated severe existing staff shortages. Nursing numbers are falling - the latest figures from the Nursing and Midwifery Council show that more EU nurses are now leaving than joining the UK register'; and doctors from Europe are being driven by the uncertainty to seek jobs outside the UK. ${ }^{10}$ Recruiting staff to fill these gaps will be costly, and whatever system is put in place will almost certainly be more complex than the current model.

Preparations for the worst case no deal scenario are ramping up, with discussions intensifying between the Department of Health and Social Care and the pharmaceutical and device companies. ${ }^{12}$ But given the complex supply networks, each hospital trust is expected to make its own preparations, including assessing the risks and identifying vulnerabilities in their supply chains. This is a massive task for services that are already stretched, as it will require detailed scrutiny of almost all existing contracts by experts in international trade law.

If the prime minister can get her Chequers deal or something like it through parliament, will this be less damaging for health? It would keep the UK in the single market for medicines and devices and would retain reciprocal healthcare schemes at least until $2020 .{ }^{13}$ But it offers no solution for the predicted staffing or funding crises, and key aspects of the deal are still to be hammered out. ${ }^{14}$ The Faculty of Public Health has called on the government to ensure that hard won standards and protections for public health are maintained after Brexit, ${ }^{15}$ but the value of a verbal commitment by ministers is, in the current turmoil, questionable.

\section{Need for informed consent}

The referendum campaign was marred by misinformation-most infamously that Brexit would deliver an extra $£ 350 \mathrm{~m}$ a week for the NHS. It was also marked by a failure to highlight the important benefits of being part of Europe. These include public health gains, research collaboration, progress for rare diseases, ${ }^{7}$ healthcare reciprocity, cooperation for drug regulation, stronger pharmacovigilance, and faster access to new drugs and devices. More broadly, the EU continues to offer the potential for cultural exchange, sustained peace, internationalism, and economic prosperity. Politicians on both sides now acknowledge that, deal or no deal, Brexit will leave the UK worse off. Like a patient before an operation, the British people must now be allowed to make a fully informed decision in a second referendum.

This is a view supported by Conservative MP and chair of the Health and Social Care Select Committee, Sarah Wollaston. 
She and three fellow medically qualified MPs from all main parties have proposed an amendment to the forthcoming House of Commons vote. If passed, this would make withdrawal from the EU conditional on a second referendum, allowing the British people to properly weigh up the choice between the proposed deal and potentially a no deal or remaining in the EU. ${ }^{16}$ Whatever the outcome, the UK could then move forward knowing that the decision had been made on the basis of informed consent and the best available evidence. The BMA and the RCN are already campaigning for a people's vote on the final deal and are seeking support from MPs. If the prime minister is unable to get her proposed deal through cabinet or parliament and we are heading for a no deal Brexit, the principle remains that this should be subject to informed consent through a people's vote.

Whatever your views on Brexit, we ask you to consider adding your voice to this call for a people's vote by telling your MP that you want an informed choice based on what you now know. You could also share this information with your colleagues and patients. Data from a recent YouGov poll shows that those who believe that Brexit will have a detrimental effect on the NHS are more likely to vote remain in a people's vote. ${ }^{17} \mathrm{We}$ believe the evidence of a detrimental effect on the nation's health is clear. Please join our call for a people's vote on the final Brexit deal.

Competing interests: We have read and understood BMJ policy on declaration of interests and have no relevant interests to declare.

Provenance and peer review: Commissioned; not externally peer reviewed.

See also: https://www.bma.org.uk/collective-voice/influence/europe/brexit, https:/ /www.rcn.org.uk/news-and-events/news/rcn-calls-for-referendum-on-final-brexitdeal, https://www.rcn.org.uk/professional-development/publications/pdf-006981
1 At-a-glance: The new UK Brexit plan agreed at Chequers. BBC News 2018 Jul 7. https:/ /www.bbc.co.uk/news/uk-politics-44749993

2 Appleby J, Dayan M. Causes for concern for the NHS after Brexit. BMJ 2018;363:k4767. $10.1136 / \mathrm{bmj} . \mathrm{k} 4767$

3 Gill M, McKee M, Brown MM, Godlee F. Brexit is bad for our health. BMJ 2018;361:k2235. 10.1136/bmj.k2235 29794034

4 BMA. No Deal would be catastrophic. Aug 2018. https://www.bma.org.uk/news/2018/ august/no-deal-would-be-catastrophic

5 Hancock M. Government's preparations for a March 2019 'no deal' scenario. 23 Aug 2018.

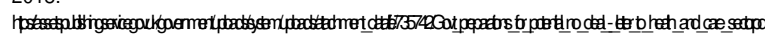

6 BMA. "No one could have imagined the extent of the complications that Brexit would bring." Press release 23 Aug 2018. https://www.bma.org.uk/news/media-centre/pressreleases/2018/august/no-one-could-have-imagined-the-extent-of-the-complications-thatbrexit-would-bring

7 Hawkes N, Wise J, Armstrong S, Moberley T. Braced for Brexit. BMJ 2018;363:k4724. 10.1136/bmj.k4724

8 McKee M. Why we must stay in the European Atomic Energy Community. BMJ 2017;358:j3527. 10.1136/bmj.j3527 28747305

9 RCN. Overall increase in nurses and midwives masks "severe workforce instability." 7 Nov 2018. https://www.rcn.org.uk/news-and-events/news/overall-increase-in-nurses-andmidwives-masks-severe-workforce-instability

10 Schumann A. Brexit won't build a physical wall, but the boundaries it will create will be significant. BMJ Opinion Nov 2018.

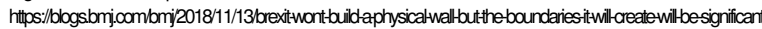

11 BMA. EU Survey April 2017.

https://www.bma.org.uk/collective-voice/influence/europe/brexit/eu-survey

12 Dickson N. No deal? Not a happy prospect for life after March 2019. BMJ 2018;363:k4770. 10.1136/bmj.k4770

13 Hervey TK, Monnet J. Reciprocal healthcare arrangements after Brexit. BMJ 2018;363:k4727. 10.1136/bmj.k4727.

14 Dayan M. What does the Chequers plan mean for the NHS? 170ct 2018. https://www. nuffieldtrust.org.uk/news-item/what-does-the-chequers-plan-mean-for-the-nhs

15 Faculty of Public Health. The "Do No Harm" campaign. https://www.fph.org.uk/policycampaigns/campaigns/brexit/a-do-no-harm-amendment-to-the-eu-withdrawal-bill/

16 Wollaston S, Williams P. There is no version of Brexit which will benefit the NHS-only varying degrees of harm. BMJ Opinon, 13 Nov 2018. https://blogs.bmj.com/bmj/2018/11/ 12/there-is-no-version-of-brexit-which-will-benefit-the-nhs-only-varying-degrees-of-harm/

17 Ingrid T. Concern about NHS is key factor in shift in views on Brexit. BMJ 2018;363:k4799. 10.1136/bmj.k4799

Published by the BMJ Publishing Group Limited. For permission to use (where not already granted under a licence) please go to http://group.bmj.com/group/rights-licensing/ permissions 